\title{
Jacek Makuch
}

Dr inż.

Politechnika Wrocławska, Wydział Budownictwa Lądowego i Wodnego;

Katedra Mostów i Kolei

jacek.makuch@pwr.edu.pl

DOI: 10.35117/A_ENG_18_06_05

\section{Activities indispensable for starting of an attractive suburban rail system on the example of Wroclaw}

\begin{abstract}
The article reviews the up to date activities dedicated to enlarge the level of rail utilization in service of the city traffic in Wrocław. An example of Berliner S-Bahn was called. Author's proposal of a suburban rail system for Wrocław was presented. The range of indispensable investment and non-investment activities was analyzed. The problem of lack of coordination of activities, dilemmas related to the choice of alternative solutions and possible threats were pointed out. In the article's recapitulation a new way of planning and execution in regard of the analyzed problems was proposed.
\end{abstract}

Keywords: Suburban rail; Rail transport infrastructure

\section{Introduction}

In the autumn of 2017, Wrocław University of Technology, at the request of the Marshal's Office of the Lower Silesian Voivodship, prepared a study regarding the possibilities and conditions for the Wrocław Agglomeration Railway [8], which the provincial government, in consultation with the cities and communes of the Wrocław agglomeration, has been planning for some time.

The author of this article found himself invited to participate in the team performing this study. Its task was to propose and analyze an indirect variant between the "minimal" solution (without infrastructure development) and the "maximum one". The purpose of this article is to present the conclusions of the considerations and analyzes carried out.

\section{The use of railways to handle city traffic in Wroclaw}

The comprehensive traffic research in Wrocław [12] carried out at the turn of 2010 and 2011 shows that $35.26 \%$ of travels carried out in the city were carried out with collective transport unfortunately only $0.10 \%$ ! Such a marginal share of the railway in servicing urban traffic may come as a surprise, given the fact that in comparison with other Polish cities, Wrocław has a very well developed railway infrastructure. The railway lines with the following stations: Główny, Mikołajów, Nadodrze (once also Świebodzki) circulate the city center area from the south, west, and north and radiate in 11 directions. The suburbs are supplemented with elements of perimeter routes serving freight traffic. Such a well-developed system results from historical conditions - Wrocław until 1945 lay within the borders of Germany, which from the beginning of the railway development were in the world's leading countries in this respect.

Lack of an attractive alternative to car trips generates a very disturbing phenomenon, which is the increase in the motorization index, which results in a significant deterioration of the quality of life in the city (traffic congestion and air pollution). In Wrocław, in the period from 2007 to 2012, ie over a period of only five years, the ratio increased by as much as $22 \%$ (from 441 to 540 cars registered per 1000 inhabitants) [12]. 
Local authorities, recognizing this problem, have been trying to turn the railway into the public transport system of urban and agglomeration traffic for some time. For several years, within Wroclaw, you can travel by train based on the urban tariff system (Urbancard), as reported by diagrams posted at bus stops and on the Internet (Fig.1). The daily number of calls offered on individual routes also increases every year. Such actions are still possible to achieve by investing only in new rolling stock, bypassing the infrastructure. Such a possibility will soon be exhausted - when the capacity reserves "slumbering" still in the infrastructure will be used, which is the result of regress, which occurred in passenger rail traffic after the period of systemic transformation (reduction in the number of trains, suspension, and liquidation of the line).

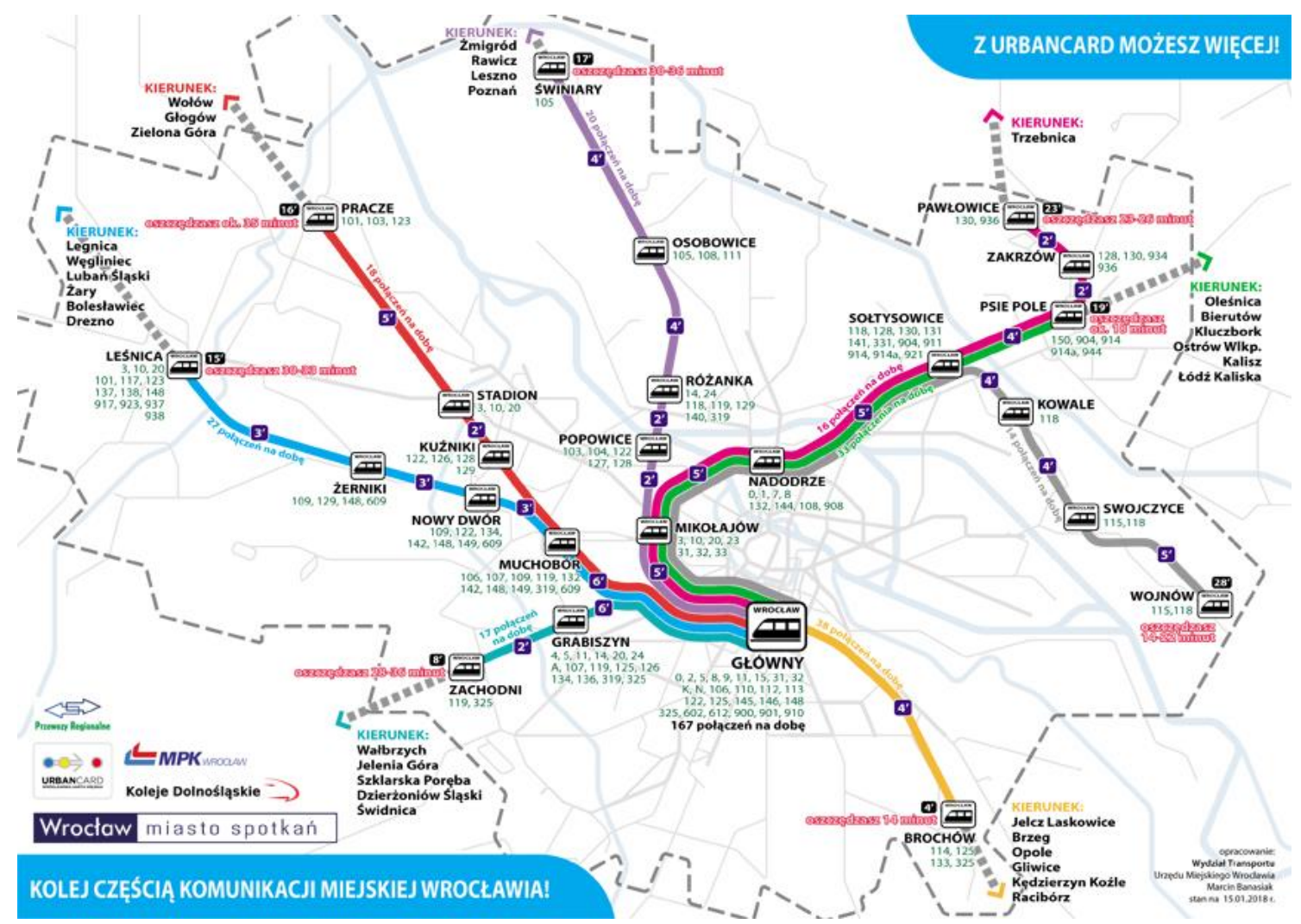

1. The possibility of traveling by rail with city tickets in Wrocław [7]

In order to encourage the inhabitants of the city to make greater use of railways in their daily trips, for some time in the local media attention has been drawn to very attractive times of traveling by rail - in relation to analogous travels by trams or buses [2]. Unfortunately, we are dealing here with some kind of understatement (a small fraud), because the presented times do not take into account the average waiting time for the start of the journey, which results directly from the frequency of running of vehicles, and this is the case of trams and buses is several times more favorable than in the case of trains. For example: from the Wrocław Mikołajów station to the Wrocław Główny station (between which the train takes 6 minutes and the tram takes 22 minutes) 83 trains depart daily, while tram lines from the "Zachodnia" stop on Legnicka Street in the direction of the center in the working day perform a total of 528 courses - more than 6 times more, similarly from Zakrzów - towards the center, 16 trains a day depart, while 128 and 130 bus lines provide a total of 95 courses that is also about 6 times more.

In recent years, passenger rail transport has been reactivated on two routes: in 2009 from Psie Pole to Trzebnica, and in 2017 - from Sołtysowice to Wojnowo. In the near future, 
further reactivations are planned: from Wojnowo to Jelcz Miłoszyce and from Wrocław to Świdnica through Sobótka. In recent years, three new railway stops have also been built: in 2011 Wrocław Stadion, in 2014 - Wrocław Grabiszyn, and in 2015 - Wrocław Różanka.

In order to make it easier for passengers to get acquainted with the offer of passenger rail connections, the local self-government carrier (Koleje Dolnośląskie) uses in its schedules and diagrams a digital-format description of the line (D1, D3, ...) [6]. Along with the correction of timetables in December 2017, Koleje Dolnośląskie opened the D7 (first urban) line running through the Wrocław Główny station. A similar solution, although with slightly lower frequencies, used Przewozy Regionalne PKP already in 2003 for two routes: from Oleśnica to Strzelin (AGLO 1) and from Żmigród to Jelcz-Laskowice (AGLO 2), unfortunately, this solution only functioned for several years.

The problem of the lack of proper use of railways to service public transport of the Wrocław agglomeration has been noticed for a long time. Over the last 40 years, many concepts have been developed to launch a municipal or agglomeration railway in Wrocław. These concepts (number 29!) Were presented by the author in a separate report at the INFRASZYN conference [9].

\section{Berlin S-Bahn}

In the world, urban or agglomeration systems operate in a variety of diametric, radial, peripheral systems, or as combinations thereof. It is impossible to state clearly which of the models is the most advantageous, because with differentiated local conditions sometimes different systems allow achieving the most beneficial effects.

In this chapter, a short description of the system functioning in Berlin was decided, because it became for the author of the article a kind of reference level for his own proposition - presented in the next chapter.

In the case of Berlin and its suburbs, the role of urban and agglomeration rail transport is played by the S-Bahn (Fig.2). Two diametrical routes intersect in the city center:

- east-west direction, so-called "Stadtbahn" built on a flyover,

- north-south direction, so-called "Nord-Süd S-Bahn" built partly in the tunnel.

The intersection of these routes is "Friedrichstrasse" - a transfer station, not only between S-Bahn trains but also long-distance and regional trains, subways, trams and buses, located in the city center. In the suburbs, both diameters branch out in several separate directions.

Berlin S-Bahn also has a perimeter route around the center - the so-called "Ringbahn" or "Hundekopf" (dog's head - from the shape of the waveform).

According to timetables from December 2017, during peak business days on the central section of east-west diameter, S-Bahn trains operated with frequencies: S3 - every 20 min, S5 - every $10 \mathrm{~min}, \mathrm{~S} 7$ - every $10 \mathrm{~min}, \mathrm{~S} 9$ - every $20 \mathrm{~min}$ - on average, every 3 and 1/3 minutes on average. Analogically for north-south diameter: S1 - every $10 \mathrm{~min}, \mathrm{~S} 2$ - every 10 min, S25 - every $20 \mathrm{~min}, \mathrm{~S} 26$ - every $20 \mathrm{~min} \mathrm{-} \mathrm{that} \mathrm{is,} \mathrm{also} \mathrm{on} \mathrm{average} \mathrm{every} 3$ and 1/3 minutes. On the length of the perimeter line - wherever only S41 and S42 circulate - every 5 minutes, wherever they are supported by other lines - even more often: on Ostkreuz - together with S8 - every $20 \mathrm{~min}$ and with S85 - also every $20 \mathrm{~min}$ - or also on average every 3 and 1/3 minutes, similarly on Sudkreuz - together with S45 - every 20 min and with S46 - also every $20 \mathrm{~min}$ - that is, on average also every 3 and 1/3 minutes. S-Bahn trains in Berlin account for as much as $28 \%$ of journeys made by public transport, which is $7.5 \%$ of the total share of all types of travel [5]. If we add Berlin U-Bahn (metro) to this, these shares will be $62 \%$ and $16.7 \%$ respectively. 


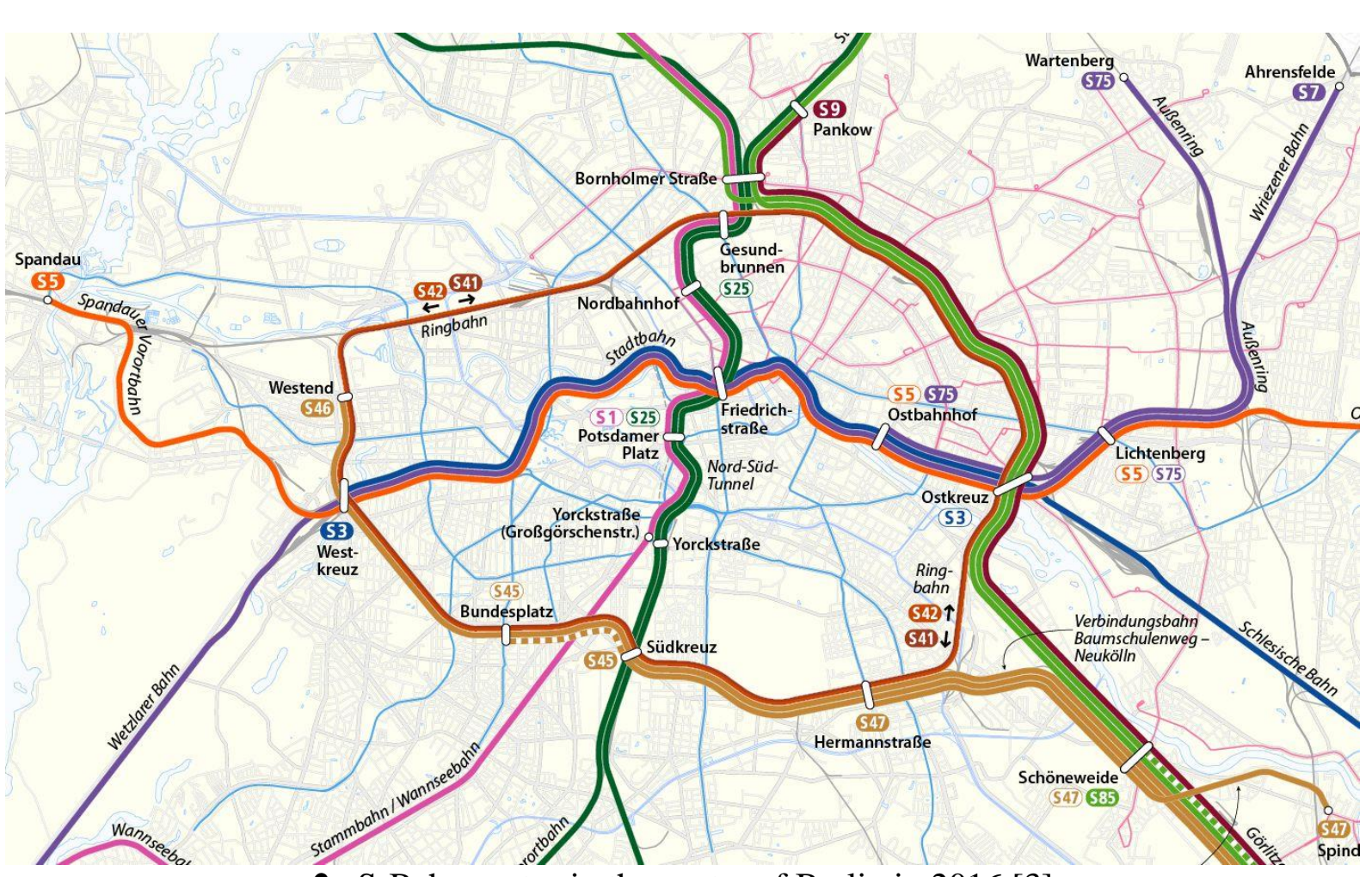

2. S-Bahn routes in the center of Berlin in 2016 [3]

S-Bahn trains in Berlin and its suburbs, due to the different way of powering the vehicles with electricity (the third rail instead of the overhead contact line), run only along the designated tracks (they do not share them with tracks for regional and long-distance trains) although a significant part of their routes runs parallel to the classic railway line, using shared tracks.

\section{An original proposition of the agglomeration railway system for Wroclaw}

The proposed solution is to some extent modeled on the model of the S-Bahn railway operating in Berlin. Wrocław, which in 2016 had a population of 637,000 , is a city more than five times smaller than Berlin with 3.4 million inhabitants (although comparing the urban areas the disparity is somewhat smaller - three times), therefore modeling on its example refers not so much to the scale of the solution, the same model.

In the proposed solution for Wroclaw (Fig. 3), it is assumed to create two crosscountry routes of the agglomeration (they will be called "red" and "blue" intersecting almost perpendicularly, with the possibility of changing the intersection. In contrast to Berlin, the diameter in the east-west direction (blue), due to the Wrocław conditions, ends blindly before the area of the center (in the Wrocław Świebodzki station) - in fact, we can call it "halfdiameter", although not it is settled that such a state should be treated as a target. Theoretically, it is possible to route the route in the tunnel under the center area and include, for example, line 292 in Swojczyce (the dotted line in Figure) [10].

Also in contrast to Berlin, the location of the interchange node called "Góralska", located at the intersection of the two proposed diametrical routes (large brown circle in Figure 3 ) falls in an unattractive place. Currently, these are the edges of industrial plants or garden plots - although it is not said that in the near future the city will not "get closer" to these areas. Also in contrast to Berlin, the proposed "Góralska" node will allow for a poorer "fan" of possible transfers - without long-distance and regional trains.

The proposed solution provides for a specific scope of the system's impact, i.e. completion of the routes of the agglomeration railway lines in the region (outside of 
Wrocław). In this article, however, these issues have been omitted, because from the point of view of formulated conclusions - they turn out to be insignificant.

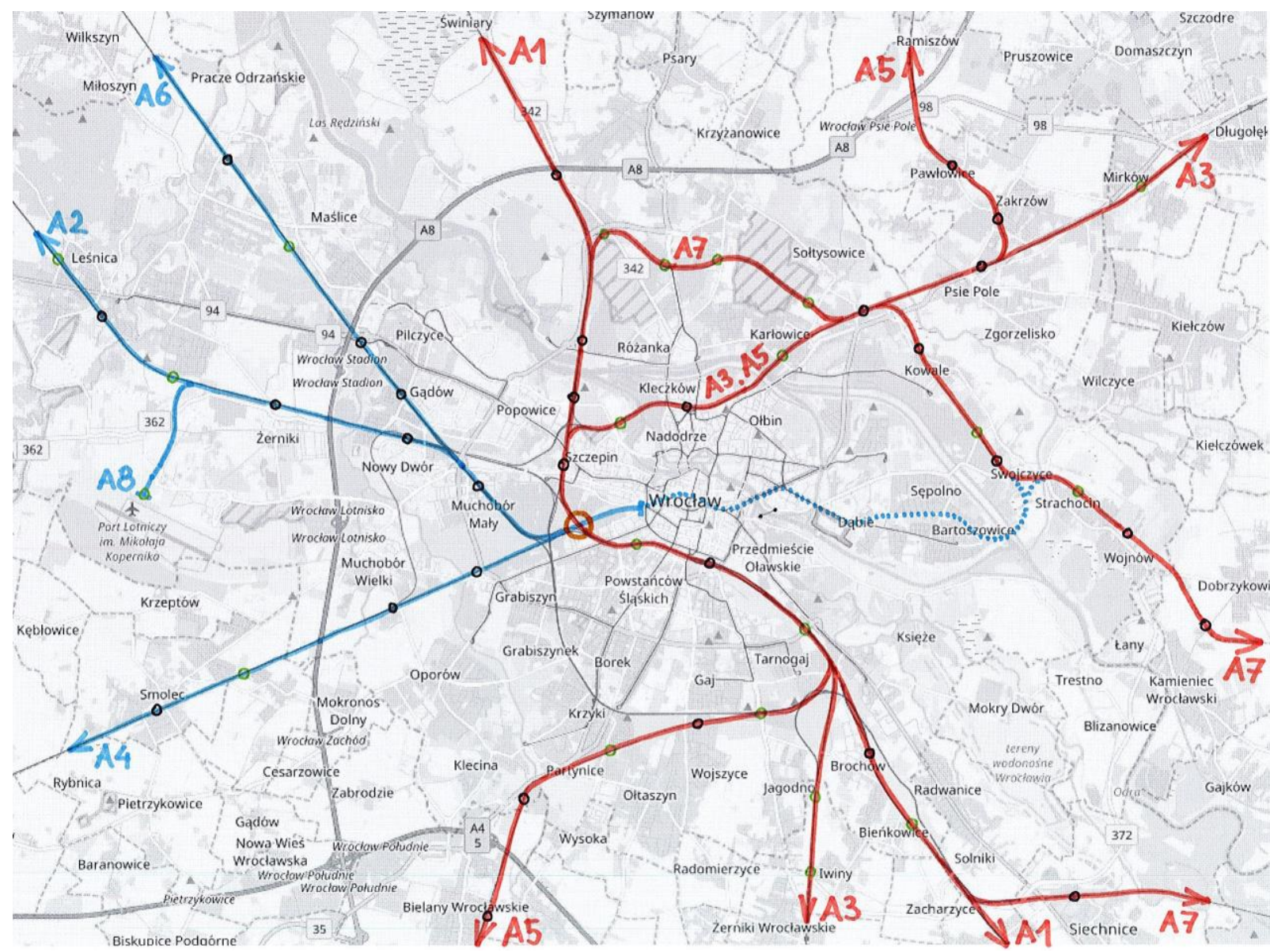

3. A proposal of the agglomeration railway routes in Wrocław (in the background used [4])

In the proposed solution, it was assumed that on each of the two diameters (red and blue), there would be 4 lines of the agglomeration railway (Fig. 3), which with a measure of 30 minutes would give the central sections of both diameters trains every 7.5 minutes. With proper synchronization of the timetables on both diameters, it would be possible to minimize the changeover time at the "Góralska" node between two perpendicular directions up to 3 and $3 / 4$ minutes.

The applied lines of the agglomeration railway line: A1, A2, etc. refer to the first letter of the word "aglo", and the numbers are assigned according to the rule: odd - for the red diameter line, and even - for the blue line. For the red diameter, opposite directions were associated due to:

- type of traction and "monorail" - direction "trzebnicki" with "Kobierzycki" (A5),

- similar line parameters (A1 and A3),

- the possibility of creating a circular line (A7).

\section{Necessary investment activities}

The implementation of the proposed solution presented in the previous chapter requires the following necessary investment activities:

1. restoring the function of railway connections service at the Wrocław Świebodzki station, 
2. partial reconstruction of the track system of the 274 line ("Wałbrzych") between the branch office of the WSB and the station Wrocław Świebodzki,

3. construction of a new interchange "Góralska", with connection to the transport infrastructure: a new street (e.g. connection of Góralska and Tęczowa St. with a viaduct over railway line 274), bus lines, pedestrian routes, a new tram route (e.g. from Orląt Lwowskich),

4. revitalization of the 285 railway line to Świdnica through Sobótka (with the option of rebuilding the 310 to Niemcza line),

5. revitalization of the 292 railway line on the section: Wrocław Sołtysowice - Jelcz Miłoszyce,

6. revitalization of the 292 railway line on the section: Wrocław Sołtysowice - Wrocław Osobowice (with its subsequent electrification),

7. reconstruction of railway switch 762 Jerzyny - Teresin together with checkpoints,

8. construction of a new railway line from the Wrocław Żerniki station to the Airport terminal.

However, the implementation of the above measures will not provide the possibility of introducing on both diameters a 30-minute cycle of agglomeration trains, because it would significantly reduce the remaining railway traffic (long-distance trains, regional trains, freight) - which should be considered unacceptable at present. In order to obtain the postulated 30 minute measure, the following investment activities are necessary:

11. reconstruction of track heads of the Wrocław G1. Station on both sides, in order to enable the agglomeration trains to stop at the existing platforms 5 and 6 (or the newly built island double-deck platform 5),

12. collision-free operation of two tracks intended exclusively for agglomeration trains above or below tracks connecting platforms from 1 to 4 Wrocław G1. Station with tracks of depot and locomotives (in order to avoid traffic collisions of agglomeration trains with the movement of long-distance and regional trains set or abandoned),

13. allocation of tracks 203 and 204 on the section between the Wrocław Główny Station and the planned new Wrocław Armii Krajowej stop (located under the overpass in this street) exclusively for agglomeration train traffic, and tracks 201 and 202 - for longdistance and regional train traffic, both for lines 132 ("Opolska") and 276 ("Strzelińska")),

14. collisionless tramlining of tracks for agglomeration trains in relation to tracks for longdistance and regional trains between the planned new Wrocław Armii Krajowej stop and the diversion of lines 132, 276 and 285 (the area of viaducts in the streets of Gazowa-Karwińska),

15. addition of the fourth track along the section between the Wrocław Głogów station and the Wrocław Grabiszyn branchpost and the destination of one pair of tracks exclusively for agglomeration train traffic, and the other - for long-distance and regional train traffic,

16. collision-free carrying out of two tracks intended exclusively for the movement of agglomeration trains over the branch Wroclaw Grabiszyn (in order to avoid the collision of traffic of agglomeration trains with the long-distance and regional train traffic),

17. addition of two new tracks designed exclusively for the movement of agglomeration trains on the section from the branch Wroclaw Grabiszyn to the station Wroclaw Mikołajów,

18. collision-free division of tracks for trains "from Nadodrze" (line 143) in relation to trains "to Poznań" (line 271) between Wrocław Mikołajów station and departures of lines 271 and 143 (viaducts over Ścinawska, Starograniczalna - Gnieźnieńska streets). 
19. adding additional tracks to bypass the Wroclaw Mikołajów trains,

20. addition of the second track for agglomeration trains within link 757 (between the proposed interchange "Góralska" and the station Wrocław Muchobór)

21. collision free line 292 in relation to line 143 at the Wrockaw Soltysowice station.

Tasks marked with numbers from 11 to 17 are aimed at obtaining on the red diameter on the section from Wrocław Mikołajów station through Wrocław Gł., To the planned new Wrocław Armii Krajowej stop - a separate pair of tracks (in two opposite directions) intended exclusively for the movement of agglomeration trains, parallel to the analogous pair of tracks for long-distance and regional trains. Such activities are necessary to create an attractive agglomeration railway system, which is confirmed by numerous foreign examples, and even national ones: the Warsaw cross-city line, the Tri-City SKM, the currently implemented "extension" of tracks on the Kraków Gł. Section - Kraków Zabłocie.

It is somewhat easier in the case of the proposed blue semiconductor, as the distance of reactivated train traffic to the station Wrocław Świebodzki does not anticipate the movement of long-distance and regional trains. The problem is only a single-track link between Wrocław Muchobór station and the branch office of the WSB - hence the need to carry out the task number 20, for which the direction "to Muchobór" is proposed to partially use the trace of "demolished" liaison 760.

In addition to the planned interchange "Góralska", the two most important elements of the described network of the agglomeration railway will be Wrocław G1. And Świebodzki. The first of them will become a stopover for agglomeration trains - that's why it will not require extensive infrastructure, two tracks with two single-edge platforms, or with one insular double-deck one will suffice. The latter, however, will be the leading start/end station for agglomeration trains - which requires a much larger number of tracks and platforms. Fortunately, the Wrocław Świebodzki station - expanded several times in its history, has the necessary potential. It is assumed that for the needs of the postulated 30-minute cycle, reactivate 4 platform edges (one edge platform 1, double-edge island platform 2 and a singleedge platform 4).

The next investment tasks necessary to obtain a 30-minute tactic in the movement of agglomeration trains is to build in appropriate locations on the lines that are planned to be left as one-stop: 326 (to Trzebnica) and planned for reactivation: 292 (Jelcz Miłoszyce - Wrocław Osobowice), 285 (to Świdnica) and 310 (to Niemcza).

Finally, investment activities should be listed, which are not necessary conditions or due to the need to obtain a 30-minute measure, nor because of the need to launch the eight proposed lines shown in Figure 3, but are necessary to make the proposed solution attractive to passengers, and these are the following activities:

- construction of new railway stops (proposals for their location are shown in small green circles in Figure 3),

- improvement of integration of existing railway stops with tram and bus transport, for example at Wrocław Mikołajów stations (new access for passengers); Wrocław Nadodrze and Wrocław Różanka (running tram and bus lines under the railway line just like it was done in Dresden at the Dresden Mitte station, and it is going to be done at the Dresden-Strehlen stop).

\section{Necessary non-investment activities}

In order to obtain the requested tact of 30 minute agglomeration trains, apart from the infrastructural investments listed in the previous chapter, it is also necessary to change the "philosophy" of railway timetables on the national scale, since it is practically impossible (but also not advisable) that agglomeration trains in Poland only used its own tracks - regardless of the long-distance and regional train traffic (as in Berlin). Therefore, when constructing a 
timetable, it would be necessary to first plan the movement of agglomeration trains in all railway junctions with this type of traffic, and only in the second place, between trains "fit in" the movement of regional and long-distance trains - that is exactly the reverse, as it is done today.

With such a way of arranging timetables, the rule of applying cyclical departure times also for long-distance trains is beneficial [1, 11], provided, of course, that the measure used for long-distance trains will be a multiple of the measure used for agglomeration and regional trains.

\section{Problems with lack of coordination of activities}

In 2015, the new Wrocław Grabiszyn railway station, planned for many years, was launched on line 274. Eight years earlier, in 2007, a flyover carrying out collision-free street was built in the same place. Klecińska (being a part of the downtown beltway) over the railway line 274 (previously there was a railway crossing, category A). For many years, the Klecińska Street has been run by bus lines connecting the southern part of Wrocław with block housing estates: Nowy Dwór, Kuźniki, Kozanów - there are three lines: 126, 134 and 136. They pass over the newly built railway station, unfortunately without the possibility of taking passengers off and picking them up, and to the nearest bus stops both one way (FAT) and the other (ROD Education) is about $500 \mathrm{~m}$. At the time of design and construction of the flyover, it was known that in the future there will be a railway stop - but the "highway" for cars was built, and the needs of residents traveling by public transport were completely ignored.

In 2017, new bridges were built: railway and road between Swojczyce and Strachocin, running along the Odra-Widawa flood channel. The investment was made as part of the modernization of the Wrocław Water Junction. It is a pity that it was not thought that a new road bridge would be built on the south, and not like the previous one on the north side of the railway bridge. This would allow creating a bypass connecting Swojczycka with Strachocińska Streets, omitting two railroad crossings, which in the case of launching the railway line of agglomeration trains will be much more frequently closed. It would seem that it would be good - let the travelers on this route change to trains, only that for the residents of Strachocin and Wojnowo the basic public transport is the bus route 115 that overcomes both these journeys. The railway line is not able to replace this connection, because it is heading to a completely different, much less attractive center.

Over 30 years ago, between the "old" Zakrzów and the railway line 143, the "Sobieski" block estate was built. From that time, it is planned to build a railway stop in this place. Until recently, on the second (southern) side of railway line 143 in this place, there were garden plots and arable fields. It was also possible to designate these areas for housing, which would give a solution similar to the Italy of Warsaw - an estate with a centrally located railway station and a system of communication routes radiating from this point. Unfortunately, the city decided to allocate these areas for industrial development.

\section{Dilemmas of choosing alternative solutions}

As it was mentioned in the previous chapter, on the 143 railway line in the place where the Sobieski block housing estate is located on its northern side, the construction of a railway stop has been planned for many years. Two bus lines run from the estate to the city center (141 and D), and for a few years also a short delivery line (150) - only to Psie Pole. In case of commencing agglomeration trains, both on railway line 143 and 326, which is included in line 143 only at Psie Pole, the frequency of agglomeration trains to the center at the planned new stop at Sobieskiego will be twice as low as in the place one stop further towards center means on the Dog's Field. There is, therefore, a doubt: will it not be better to abandon the 
construction of a railway stop at the Sobieski housing estate, in exchange for providing convenient transfers from bus lines 141,150 and D to agglomeration trains at Psie Pole?

In 2017, design works were carried out related to the revitalization of the monorail line 292 on the section Jelcz Miłoszyce - Wrocław Sołtysowice. This is a section about $21.5 \mathrm{~km}$ long. Many years ago, during the period of both freight and passenger traffic, a crossing of trains was possible in addition to ending stations in three places: in Nadolice, Dobrzykowice, and Swojczyce. Meanwhile, the design unit recommended as the most advantageous - the variant in general without passing! The choice was justified by the shortest travel time obtained in this variant. Fortunately, the ordering party did not succumb to this argument and forced the project unit to execute at least one pass along the way. From the point of view of ensuring the flexibility of the infrastructure - in the event of random delays, according to the author of the article, it would be advisable to recreate all three passes.

\section{Threats}

The main goal guiding the idea of establishing an agglomeration railway is to improve public transport service - perceived as a whole. Unfortunately, you should be aware of lurking traps and threats. A good example may be the southern housing estates of Wrocław: Ołtaszyn, Wojszyce, and Jagodno. Restoration of railway traffic on line 285 will cause frequent closure of railroad crossings located in Zwycięska, Ołtaszyńska, Grota-Roweckiego, and Buforowa Streets, through which the following bus lines cross the following districts: 110, 112, 113, $127,133,612900 \mathrm{~L}, 900 \mathrm{P}, 910$. It may turn out that the benefits achieved due to the launch of the agglomeration will be damaged by the deterioration of the service provided by the buses.

\section{Summary}

In the field of creating agglomeration rail systems, there is no broader experience in Poland. It can be said that currently operating solutions such as SKM in Warsaw, Łódź ŁKA, Gdansk PKM, or Krakowska SKA are just "fledgling". The only exception is Tricity SKM, operating for over sixty years - but due to the layout of the route (one "thread" connecting neighboring cities), it can be treated as a specific case.

Wrocław, compared to other Polish cities, can boast of an impressive number of the hitherto concept of launching an agglomeration railway [9]. Unfortunately, with the implementation of any of them - it is much worse. This fact provokes reflection: is the approach to planning and carrying out such a task itself that is certainly correct?

Most of the authors of ideas and decision-makers intending to implement them are already aware of the need to undertake certain necessary investment activities - both in terms of rolling stock and infrastructure. But maybe it's not enough to "want more", maybe you also need to "want a bit differently"?Creating the existing conception of the agglomeration railway for Wrocław, reference was made to the experience of the development of the "traditional" railways (intensification of regional and long-distance train traffic) using known methods of operation and modifying them only by applying:

- shorter routes,

- smaller distances between stops.

According to the author, this approach turns out to be insufficient. It is necessary to reach for elements used in the case of slightly different means of urban public transport - such as metro and even trams, by applying the following - appropriate to these means of transport rules:

- fewer route alternatives, but higher frequency,

- less collision of routes, but more possible convenient changes (in collision-free intersections of these routes),

- on routes - even traffic (without overtaking),

- route completion - on the periphery, not at the central points of the system, 
- diametrical (or diametral branching) circuits, not radial, stops (stations) - in the most attractive places because of the comfort of passengers, not motor needs or terrain conditions,

- shorter stock, with more doors.

For example - referring the above principles to Wrocław conditions:

- currently, at Wrocław G1. Station, most trains end or start routes, and only a few (longdistance ones) pass through it by transit; in the case of agglomeration trains, it is necessary to do exactly the opposite - most of them should pass through Wrockaw through transit, and only single courses (at the beginning or end of the day or peak periods) can start or end the route there,

- currently, trains heading west from Wroclaw Głogów station at the branch Wroclaw Grabiszyn can "go" in several different directions - unfortunately in a collision manner; agglomeration trains are better to "round off" this post without collision, while the possibility of driving in several different directions is desirable to realize by providing convenient transfers at the proposed "Góralska" node,

- for the section Wrocław Mikołajów - Wroclaw Psie Pole, in the case of the building of an additional separate pair of tracks designed exclusively for agglomeration trains, "plan" the location of new stops or reconcile with the "slowdown" of regional and long-distance trains on this section,

- in the case of Wrocław Żerniki, Psie Pole, and Swojczyce stations, there are suggestions to change their location (if not all stations, at least the location of their platforms) in order to bring them closer to the current location of the neighboring housing.

In the scope of the proposed "want a bit differently" there is also a change in the method of arranging timetables (cyclically, with priority for agglomeration trains).

As far as the railway investment activities are concerned, it is necessary to coordinate them with the remaining elements of the urban infrastructure (mainly the road system). You should also be aware of the risks that may accompany the introduced changes (disadvantage of urban bus transport), so as to be able to minimize or compensate for their negative effects.

\section{Source materials}

[1] Chyliński P.: Krajowy zintegrowany cykliczny rozkład jazdy (KZCRJ), Przegląd Komunikacyjny $2017 \mathrm{nr}$ 4, s. 25-29

[2] Gazeta Wrocławska 22.07.2009

[3] http://silesiainfotransport.pl/wpcontent/uploads/2016/02/Topographischer_Netzplan_der_S-Bahn_Berlin.png (dostęp: 31.03.2018)

[4] http://www.openstreetmap.org (dostęp: 31.03.2018)

[5] https://en.wikipedia.org/wiki/Transport_in_Berlin (dostęp: 31.03.2018)

[6] https://www.kolejedolnoslaskie.eu/rozklady/obecne/schemat.png (dostęp: 31.03 .2018 )

[7] https://www.wroclaw.pl/files/komunikacja/kolej_15_01_2018.pdf (dostęp: 31.03.2018)

[8] Kruszyna M., Makuch J., Popiołek A., Gasz K.: Koncepcja rozwoju pasażerskiego transportu kolejowego w Aglomeracji Wrocławskiej poprzez uruchomienie Wrocławskiej Kolei Aglomeracyjnej; Politechnika Wrocławska, Wydział Budownictwa Lądowego i Wodnego, Raport serii SPR nr 32/2017

[9] Makuch J.: Dotychczasowe koncepcje uruchomienia we Wrocławiu kolei miejskiej lub aglomeracyjnej (prezentacja), Konferencja INFRASZYN,18-20.04.2018

[10] Makuch J.: Nowoczesne rozwiązania w transporcie szynowym miast i aglomeracji a dylematy uruchomienia we Wrocławiu kolei miejskiej; Przegląd Komunikacyjny 2011 nr 1-2, s. 41-43 
[11] Massel A.: Technika Transportu Szynowego 2006 nr 3, s. 60-69

[12] Żabiński M.: Miasto dla ludzi (prezentacja); Wrocławskie Forum Mobilności, Wrocław 17.10.2015 